\title{
One-pot efficient reductive acetylation of aromatic nitro compounds
}

\author{
Kaushik Basu ${ }^{1}$, Suchandra Chakraborty ${ }^{2}$, Chandan Saha ${ }^{2 *}$, and Achintya Kumar \\ Sarkar \\ ${ }^{I}$ Department of Chemistry, St. Paul's Cathedral Mission College, Kolkata-700009, India. \\ ${ }^{2}$ Department of Clinical and Experimental Pharmacology, School of Tropical Medicine, Kolkata-700073, India \\ ${ }^{3}$ Department of Chemistry, Durgapur Govt. College, Durgapur, Burdwan (W. B.), India
}

\begin{abstract}
An efficient one-pot reductive acetylation of aromatic nitro compounds is developed without isolating the intermediate amine. The nitro compound is efficiently reduced by sodium borohydride and catalytic amount of Pd-C in MeOH-water media in presence / absence of alkali, and the amine thus generated is acetylated by acetic anhydride in situ in excellent yields through easy work-up. The technique unveils a new route for direct conversion of synthetically accessible nitro compounds to acetamido functionality and is reproducible in large scale. The method has been successfully extended in case of nitrosophenols as well. Mechanistic rationale of this methodology is also significant.
\end{abstract}

Keywords : Nitro compound, nitrosophenols, palladium-charcoal, reductive acetylation, sodium borohydride.

\section{INTRODUCTION}

Reduction of aromatic nitro compounds to corresponding amines is an extensively studied organic transformation [1]. Diverse reagents and reaction conditions have been developed for this purpose. Conversion of aromatic amines to corresponding acetamides is also well documented [2]. Reduction of nitro group and acetylation of the resulting amine are often carried out in succession to attenuate the reactivity of amines towards electrophilic substitutions on the ring and provides important protection strategy for the amino group which is susceptible to oxidative degradation under demanding reaction conditions. The conventional two step method, however, is not without practical difficulties like loss of yield associated with the isolation and purification of the amine as the reduction product. In some cases e.g. the aminophenols, which show a marked propensity of darkening upon storage, the sensitive nature and concomitant degradation of amines may also pose a serious threat of compromising the yield of the acetylation reaction. A closer scrutiny reveals that a process of reductive acetylation where the nitro compound is reduced and the reduction product is acetylated in one-pot without isolating and purifying the intermediate amine, provides access to protected amino functionality directly from nitro substrate as and when required. In addition, it can be utilized as a method for obtaining suitable derivatives of nitro compounds which is otherwise cumbersome and difficult to prepare. However, the field of such reductive acetylations is relatively unexplored as evinced by the scanty references available. Earlier, in 1948, Kohn and Krasso reported reductive acetylation of few aromatic nitrohydocarbons and halogenated nitrophenols by refluxing the substrates in acetic anhydride and acetic acid in presence of $\mathrm{Zn}$-dust [3]. Latter on in 1961, Freifelder obtained three isomeric hydroxyacetanildes by reductive acetylation of nitrophenols by using $\mathrm{H}_{2}$, Pd-C and $\mathrm{Ac}_{2} \mathrm{O}$ in acetic acid [4]. Nitro groups in thiophene ring systems have been transformed directly to acetylamino functions by use of powdered reduced iron in $\mathrm{Ac}_{2} \mathrm{O}$ and $\mathrm{AcOH}$ medium [5-7]. A recent report highlighted the reductive acylations of 2- and 3-nitropyrroles to pyrrolylamides and pyrrolylimides achieved by catalytic hydrogenation in $\mathrm{Ac}_{2} \mathrm{O}-\mathrm{MeOH}$ medium [8]. In addition nitroarenes were converted to $\mathrm{N}$ arylacetamides by a variety of reagents such as Indium in $\mathrm{Ac}_{2} \mathrm{O}, \mathrm{AcOH}, \mathrm{MeOH}$ medium at room temperature [9], Samarium in $\mathrm{Ac}_{2} \mathrm{O}-\mathrm{AcOH}$ medium [10], $\mathrm{SmI}_{2}$ and ethyl acetate in THF medium [11]. Reductive acetylations of nitroarenes were also successful with iron- $\mathrm{AcOH}[12,13]$, molybdenum hexacarbonyl-AcOH [14], $\mathrm{Zn}-\mathrm{Ac}_{2} \mathrm{O}$ in presence of acidic $\mathrm{Al}_{2} \mathrm{O}_{3}$ [15], Pt-complex, $\mathrm{SnCl}_{4}-\mathrm{CO}$ system [16], $\mathrm{HCOOCH}_{3}-\mathrm{AcOH}-$ $\mathrm{Ru}_{3}(\mathrm{CO})_{12}$ [17], $\mathrm{Zn}-\mathrm{AcOH}$ in DMF medium in combination with acyl chloride-triethylamine [18], $\mathrm{Pd}(\mathrm{OAc})_{2}$, aq. $\mathrm{KF}$ and polymethylsilylhydrosiloxane followed by treatment with $\mathrm{Ac}_{2} \mathrm{O}$ [19]. Microbial transformations of nitro groups to acylated amines have also been reported [20]. A very recent paper reports Pt-mediated zironia supported synthesis of $N$-acyl amines from nitroarenes and acids [21]. Many of the existing methodologies however suffer from the problem of either longer reaction times or unsatisfactory yields of the acylated end product and sometimes entail the use of highly expensive reagents. An efficient general method employing commonly available and relatively inexpensive set of reagents is still lacking for the reductive $N$-acetylation of nirtoarenes and related compounds. With this view in mind an efficient, one-pot reductive acetylation of aromatic nitro compounds is devised, in which the substrate is reduced by $\mathrm{NaBH}_{4}-\mathrm{Pd}-\mathrm{C}$ in environmentally 
benign aqueous / aq. alcoholic medium followed by concomitant acetylation with acetic anhydride, without isolating the intermediate amine "Scheme 1".

$$
\left(\mathrm{R}=\mathrm{H}, \mathrm{CH}_{3}, \mathrm{CO}_{2} \mathrm{H}, \mathrm{OCH}_{3}\right)
$$

Scheme 1. Reductive acetylation under alkaline condition

\section{RESULTS AND DISCUSSIONS}

Common aromatic nitrohydrocartbons were converted to the corresponding acetamides in excellent yield through reduction with the $\mathrm{NaBH}_{4}-\mathrm{Pd}-\mathrm{C}$ in aq. methanol under alkaline condition and concomitant acetylation with acetic anhydride. To effect such reductive acetylation several reaction conditions were attempted depending on the $\mathrm{pH}$ of the medium with varying amounts of sodium borohydride but best result was obtained only under alkaline condition using 2 molar equivalent of $\mathrm{NaBH}_{4}$ "Table 1".

Table 1. Optimization of reaction condition

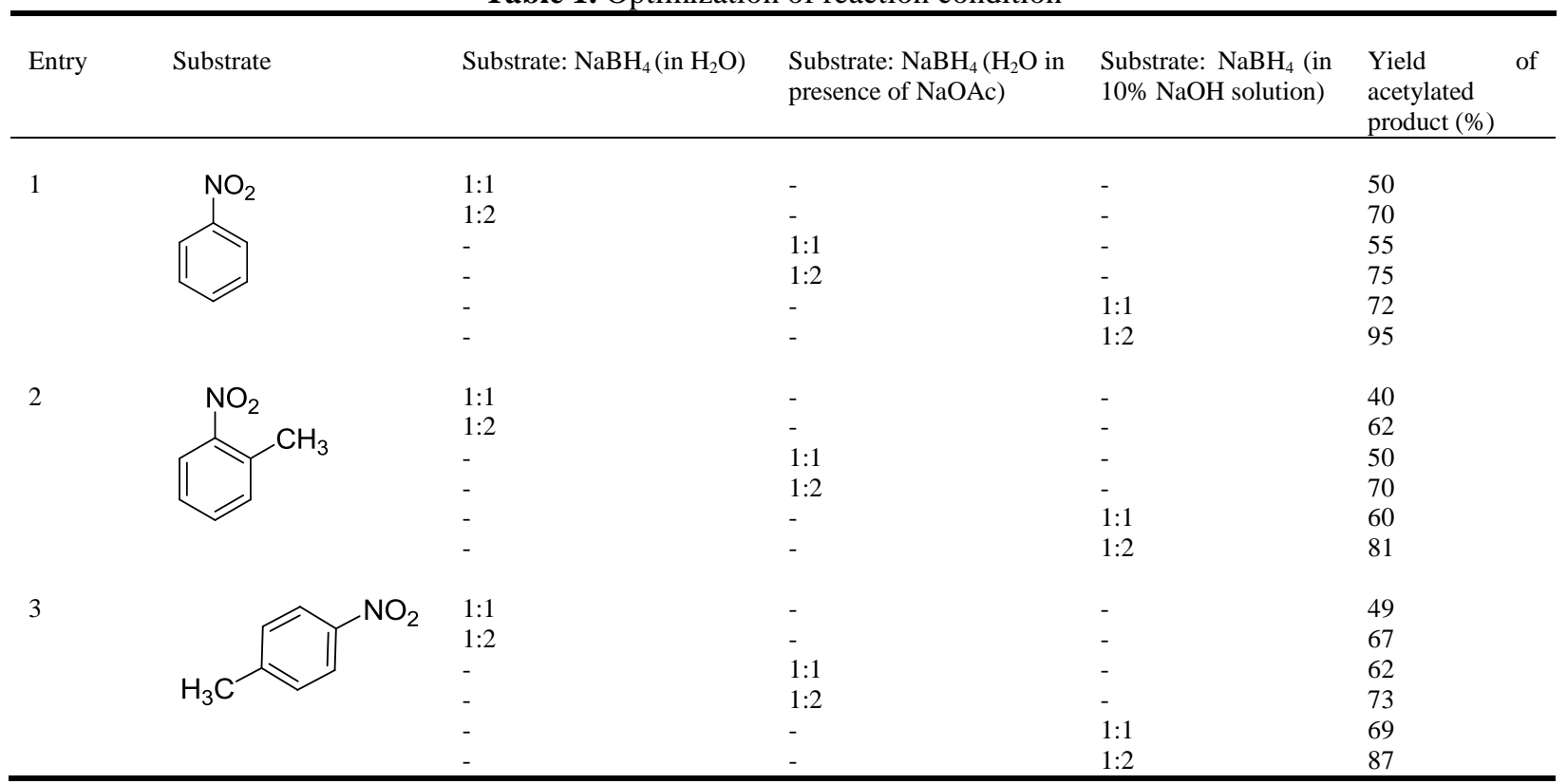

This is expected because sodium borohydride is prone to hydrolysis in aqueous solution and alkalinity of the medium is necessary to resist such disintegration of the reducing agent [22]. In addition, it may be assumed that the hydride transfer ability i.e. the reducing power of borohydride is successively increased after each hydride transfer under alkaline condition [23]. It is also important to note that substrates with acidic hydrogen like nitrocarboxylic acids must be dissolved in alkali prior to reduction; otherwise the acidic hydrogen will quench the borohydride by acid-base reaction. Thus the reductive acetylations of aromatic nitro carboxylic acids (Table 2, entries 5-9) were accomplished with excellent yields under aqueous alkaline condition after neutralizing the acid substrate. However, nitrophenols having acidic hydrogen posed a problem on adopting identical reaction conditions as above. While the ortho isomer, a less acidic (pKa 7.23) substrate than the para (pKa 7.15), was flawlessly transformed to the $o$-hydroxy acetanilide, the reaction turned out to be unsuccessful in case of the meta and para isomers, offering only intractable, tarry materials at the end of the reaction. This failure was presumably due to oxidation of intermediate compounds present under alkaline condition which also promotes formation of phenoxide ion, rendering the system more vulnerable towards such oxidation. In case of the meta isomer, though it is the least acidic (pKa 8.40) of all the regioisomers of nitrophenol, the reduction product meta-aminophenol is extremely sensitive and does not survive the alkaline reaction condition. A point to note is that in a previous report also where nitrophenols were reduced by catalytic hydrogen transfer reactions the ortho isomer was found to be a much better substrate than the para [24]. Another useful observation is from an earlier report of reductive acetylation of nitrophenols where the reaction was carried out in acidic media, namely acetic acid and acetic anhydride, good yield of hydroxyacetanilides were obtained [4]. It can be thus 
concluded that the reduction products of nitrophenols are quite stable in acid, but they are liable to degradation in strong alkali, particularly in case of the meta- and para- isomer. This idea was verified by effecting the smooth reductive acetylation under alkaline condition on nitroanisoles (Table 2, entries 12-14) where the phenolic hydroxyl group was protected through $O$-methylation. The detrimental role of alkali in apparent degradation of intermediate reduction products was further corroborated by successful reaction of meta- and para-nitrophenols under a neutral reaction condition, where alkali has been omitted altogether. Slight improvement in the yield of the acetylated product was noted for the ortho isomer as well, under such neutral reaction condition. Nitrophenols are however acidic enough to liberate $\mathrm{H}_{2}$ gas from a hydride donor like $\mathrm{NaBH}_{4}$ and in absence of alkali to ensure complete reduction of the substrate three equivalents of the reducing agent was added instead of two. Moreover, nitrosophenols are known to be an intermediate in the reduction of nitrophenols to corresponding amino compounds [25]. This prompted us to investigate the reductive acetylation of several nitrosophenols (Table 2, entries 15-18, the requisite nitrosophenols were synthesized for this purpose by nitrosation of relevant phenolic compounds [26]) under alkaline reaction condition. The low yields of the $\mathrm{N}$ acylated products again pointed to probable degradation of intermediates in alkali. The attempted reductive acetylation of nitrosophenols (Table 2, entries 31-33) under neutral condition improved the yield of hydroxyacetanildes significantly as expected. Thus it is clear that though alkaline condition is best suited for most of the other substrates, it is best avoided in case of $m$ - and $p$-nitrophenols and nitrosophenols. Two opposing factors operate here, alkali stabilizes the hydride reducing agent but makes the phenolic substrates more vulnerable leading to either low yields or complete failure, while omission of alkali stabilizes the intermediates but compromises the reducing agent. Satisfactory result for these substrates was obtained thus in neutral condition in absence of alkali "Scheme 2".

$$
\begin{aligned}
& \text { i) } \mathrm{NaBH}_{4}, 10 \% \mathrm{Pd}-\mathrm{C} \text {, } \\
& \text { R } \\
& \mathrm{CH}_{3} \mathrm{OH}, \mathrm{H}_{2} \mathrm{O}, 50^{\circ} \mathrm{C} \\
& \text { ii) } \mathrm{AC}_{2} \mathrm{O}, 60^{\circ} \mathrm{C} \\
& \mathrm{NHAc} \\
& \left(\begin{array}{l}
\mathrm{R}=\mathrm{OH}, \mathrm{CO}_{2} \mathrm{CH}_{3} \\
\mathrm{Z}=\mathrm{NO}_{2}, \mathrm{NO}
\end{array}\right)
\end{aligned}
$$

Scheme 2. Reductive acetylation under neutral condition

3-nitroacetophenone (Table 2, entry 19) and 1-nitrobenzaldehydes (Table 2, entry 20) were subjected to the reductive acetylations under alkaline condition. This resulted in complete reduction of the carbonyl group to corresponding alcohols as expected and the nitro group also underwent smooth reductive acetylation. As per our expectation the ester group of methyl $m$-nitrobenzoate (Table 2, entry 21) also proved vulnerable when subjected to the alkaline reaction condition. The substrate underwent not only reductive acetylation, but also ester hydrolysis so that the acetyl derivative of $m$-amino benzoic acid was isolated as the end product. To circumvent this problem, alkali was again omitted and the reaction was accomplished in aqueous methanol which led to the desired transformation of the nitro group without affecting the ester functionality.

To explore the applicability of the present method in heterocyclic systems two pyrimidine derivatives, namely 5-nitrouracil (Table 2, entry 22) and its 6-methyl variant (Table 2, entry 23) were subjected to the reductive acetylation under alkaline reaction condition. The substrates afforded corresponding acetamido derivatives in good yields.

In case of halogen substituted nitrobenzenes, a curious observation was the dehalogenation accompanied by the reductive acetylation of the nitro group so that all three isomers of chloronitrobenzene (Table 2, entry 24-26) and p-bromonitrobenzene (Table 2, entry 27) afforded acetanilide as the end product. To investigate any possible role of alkali in such dehalogenation reaction reductive acetylation was also carried out in neutral medium using 4-chloronitrobenzene as a substrate, but again the halogen was knocked off. This observation was consistent with reports of such halogen loss from halogen-substituted aromatic rings under influence of Pd-C catalyst [27, 28].

One limitation of the present technique is its complete failure in the case of $m$-nitroaniline and 1,3dinitrobenzene where the reductive acetylation was unsuccessful probably because of deactivation of the palladium catalyst by amino group [29].

In all the cases examined, the derivatives were crystallized from methanol/ methanol-water/ water and identified by comparing with authentic samples (whenever possible), and characterized through NMR and IR spectroscopic techniques. The results are summarized in the "Table 2". 
Table 2. Reductive acetylation of aromatic nitro compounds

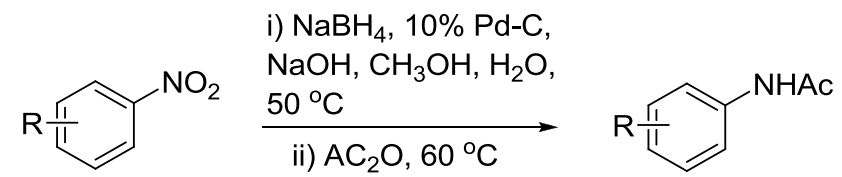

$\left(\mathrm{R}=\mathrm{H}, \mathrm{CH}_{3}, \mathrm{CO}_{2} \mathrm{H}, \mathrm{OCH}_{3}\right)$

\begin{tabular}{|c|c|c|c|c|}
\hline Entry & Substrate & Product & Yield (\%) & $\begin{array}{c}\text { M.P/ Lit. M.P. of } \\
\text { acetyl } \\
\text { derivative }\left({ }^{\circ} \mathrm{C}\right) \\
\end{array}$ \\
\hline 1 & $\mathrm{NO}_{2}$ & $\mathrm{NHA}$ & 95 & $112 / 114$ [30] \\
\hline 2 & & $\mathrm{NHA}$ & 81 & $112 / 112$ [30] \\
\hline 3 & & & 87 & 154/154 [30] \\
\hline $4^{a}$ & & & 80 & $160 / 160[30]$ \\
\hline 5 & & $\mathrm{NI}$ & & \\
\hline & & & 85 & $247 / 250[30]$ \\
\hline $6^{a}$ & & & 90 & $250 / 252[30]$ \\
\hline 7 & & & 87 & $182 / 184[30]$ \\
\hline 8 & & & 81 & 201/206 [31] \\
\hline 9 & & & 90 & $169 / 167$ [32] \\
\hline 10 & & & 70 & 199/201[30] \\
\hline 11 & & & 56 & $178 / 178$ [33] \\
\hline 12 & & & 91 & $85 / 88$ [30] \\
\hline 13 & & & 85 & $124 / 127[30]$ \\
\hline
\end{tabular}


14

15<smiles>COc1ccc([N+](=O)[O-])c(C)c1</smiles><smiles>Cc1cc([N+](=O)[O-])ccc1O</smiles>

$16^{a}$<smiles>Cc1c(O)ccc([N+](=O)[O-])c1C</smiles>

17<smiles>Cc1cc(O)c(C(C)C)cc1[N+](=O)[O-]</smiles>

18<smiles>O=[N+]([O-])c1c(O)ccc2ccccc12</smiles>

$19^{\mathrm{a}, b}$<smiles>CC(=O)c1cccc([N+](=O)[O-])c1</smiles>

$20^{a}$<smiles>O=Cc1ccccc1[N+](=O)[O-]</smiles>

$21^{a}$<smiles>CC(=O)c1cccc([N+](=O)[O-])c1</smiles>

$22^{a, b}$

$23^{a}$

$24^{a}$<smiles>O=c1[nH]cc([N+](=O)[O-])c(=O)[nH]1</smiles><smiles>Cc1[nH]c(=O)[nH]c(=O)c1[N+](=O)[O-]</smiles><smiles>O=[N+]([O-])c1ccccc1Cl</smiles>

25<smiles>O=[N+]([O-])c1cccc(Cl)c1</smiles>

26<smiles>O=[N+]([O-])c1ccc(Cl)cc1</smiles><smiles>COc1ccc(Nc2ccccc2C)c(C)c1</smiles>

132/135 [34]<smiles>CCC=CNC(C)=O</smiles><smiles>CC(=O)Nc1cc(C(C)C)c(O)cc1C</smiles><smiles>CC(C)(C)Nc1c(O)ccc2ccccc12</smiles><smiles>[Mg][Mg]</smiles>

$>260 /$<smiles></smiles><smiles>CC(=O)Nc1ccccc1CO</smiles>

110/116 [37]

NHAc<smiles>CN(C)c1cccc(C(=O)O)c1</smiles><smiles>CCNc1c[nH]c(=O)[nH]c1=O</smiles>

$>260 /-$<smiles>CC(=O)Nc1c(C)[nH]c(=O)[nH]c1=O</smiles><smiles>[X]c1ccccc1</smiles><smiles>[N]c1ccccc1</smiles> 


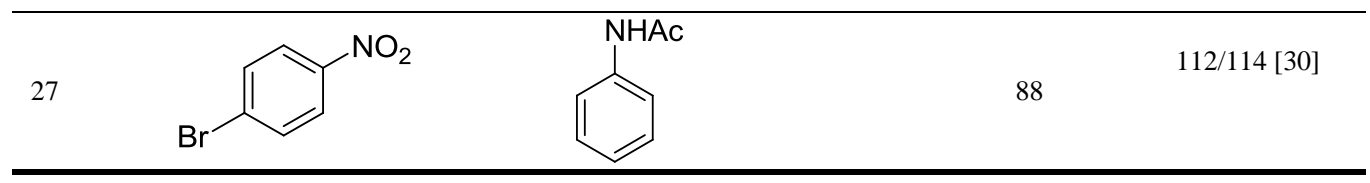

i) $\mathrm{NaBH}_{4}, 10 \% \mathrm{Pd}-\mathrm{C}$,

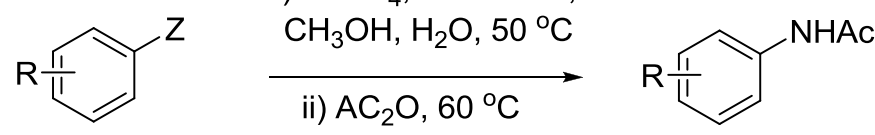

$\mathrm{R}=\mathrm{OH}, \mathrm{CO}_{2} \mathrm{CH}_{3}$
$\mathrm{Z}=\mathrm{NO}_{2}, \mathrm{NO}$

(2)

Reaction conditions: Entry 1 to 27 under alkaline condition; Entry 28 to 35 under neutral condition.

All the known products were characterized by IR, ${ }^{1} \mathrm{H}$ NMR and ${ }^{13} \mathrm{C}$ NMR data and their data are identical with reported values in the literature.

The yield refers to isolated yield.

${ }^{a}$ Spectral data is provided for these compounds

${ }^{b 1} \mathrm{H}$ - and ${ }^{13} \mathrm{C}$-NMR spectra of unknown compounds 
We have also investigated the scalability of the present method and found that the reaction was reproducible when scaled up to $0.25 \mathrm{~mol}$ (from the $0.02 \mathrm{~mol}$ substrate usually used) of the starting nitro compound, accompanied by considerable increase in the yield of the isolated acetyl derivatives. Some representative examples are enlisted in "Table 3".

Table 3. Reductive acetylation in large scale (with $0.25 \mathrm{~mol}$ of nitro compound)

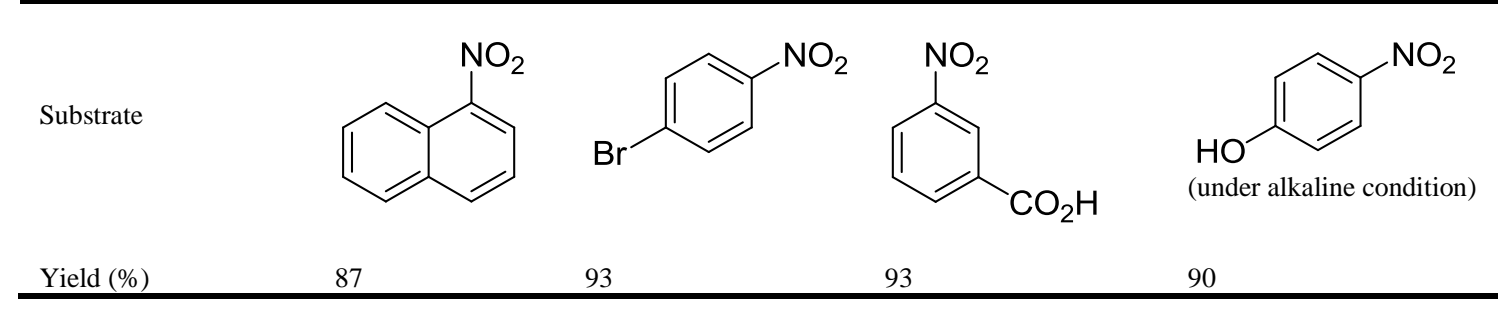

\section{EXPERIMENTAL SECTION}

Melting points were determined in open capillaries using a Zeal $76 \mathrm{~mm}$ immersion thermometer. Reagent-grade chemicals were purchased from Sigma-Aldrich and used without further purification. The Pd-C catalyst (10\% Pd) used was from E.Merck. IR spectra were recorded in $\mathrm{KBr}$ discs on Schimadzu FTIR- 8300 and NMR spectra were recorded on Bruker AV 300 and 400.

\subsection{General Procedure for the Reductive Acetylation of Nitro Compounds}

To a solution of $\mathrm{NaBH}_{4}(1.514 \mathrm{~g}, 0.04 \mathrm{~mol})$ in $20 \mathrm{ml} 1(\mathrm{~N}) \mathrm{NaOH}(20 \mathrm{ml}$ of water for neutral condition, in case of nitrophenols $\left.0.06 \mathrm{~mol} \mathrm{NaBH}_{4}\right) 200 \mathrm{mg}$ of $\mathrm{Pd} / \mathrm{C}(10 \% \mathrm{Pd})$ was added upon which hydrogen evolution started. The temperature of the reaction vessel was kept around $50^{\circ} \mathrm{C}$. Then methanolic solution $(10 \mathrm{ml})$ of the substrate $(0.02 \mathrm{~mol})$ was then added dropwise to the reaction mixture with stirring. In case of nitrocarboxylic acids the substrate $(0.02 \mathrm{~mol})$ was dissolved in $0.67(\mathrm{~N}) \mathrm{NaOH}$ solution $(30 \mathrm{ml}, 0.02 \mathrm{~mol})$ and for nitrodicarboxylic acid $1(\mathrm{~N})$ alkali $(40 \mathrm{ml}, 0.04 \mathrm{~mol})$ was used. Cessation of hydrogen evolution indicated completion of reduction within 20-30 minutes. Acetic anhydride $(3.8 \mathrm{ml}, 0.04 \mathrm{~mol})$ was then added to the reaction mixture and stirring was continued for further 30 minutes at a slightly elevated temperature $\left(60^{\circ} \mathrm{C}\right.$ $70^{\circ} \mathrm{C}$ ). The reaction mixture was then rapidly filtered under suction to remove the catalyst. On cooling the amide derivative crystallized out. In case of phenolic compounds and nitrocarboxylic acids, the amide derivative remained in alkaline solution which was precipitated by acidifying the filtrate with dropwise addition of conc. $\mathrm{HCl}$. It was collected by filtration and crystallized from hot water / water-methanol.

\subsection{Spectroscopic data for product characterization}

$N$-(naphthalen-1-yl)acetamide (Table 2, entry 4). m.p. $160{ }^{\circ} \mathrm{C}^{[30]}$; IR (KBr) 3249, 1525, $1410 \mathrm{~cm}^{-1}$; ${ }^{1} \mathrm{H}$ NMR (DMSO-d $\left.d_{6}\right): \delta 2.05\left(\mathrm{~s}, 3 \mathrm{H}, \mathrm{CH}_{3}\right), 7.62(\mathrm{~d}, \mathrm{~J}=7.5 \mathrm{~Hz}, 1 \mathrm{H}, \mathrm{Ar}-\mathrm{H}), 7.34-7.54(\mathrm{~m}, 5 \mathrm{H}, \mathrm{Ar}-\mathrm{H}), 8.02(\mathrm{~d}, \mathrm{~J}=$ $8.0 \mathrm{~Hz}, 1 \mathrm{H}, \mathrm{Ar}-\mathrm{H}) 9.52(\mathrm{~s}, 1 \mathrm{H}, \mathrm{NH}) ; .{ }^{13} \mathrm{C}$ NMR (DMSO- $\left.d_{6}\right): \delta 23.30,108.45,112.12,116.98,127.47,127.97$, $128.77,129.54,131.49,134.21,138.03,170.78$, HRMS (Q-TOF) m/z: $[\mathrm{M}+\mathrm{H}]^{+}$Calcd for $\mathrm{C}_{12} \mathrm{H}_{12} \mathrm{NO} 174.0915$, Found 174.0918.

4-acetamidobenzoic acid (Table 2, entry 6). m.p. $250{ }^{\circ} \mathrm{C}^{[30]} ; \mathrm{IR}(\mathrm{KBr}) 3305,1682,1525,1430 \mathrm{~cm}^{-1} ;{ }^{1} \mathrm{H}$ NMR $\left(D M S O-\mathrm{d}_{6}\right): \delta 2.11\left(\mathrm{~s}, 3 \mathrm{H}, \mathrm{CH}_{3}\right), 7.71(d, \mathrm{~J}=8.0 \mathrm{~Hz}, 2 \mathrm{H}, \mathrm{Ar}-\mathrm{H}), 7.95(d, \mathrm{~J}=8.0 \mathrm{~Hz}, 2 \mathrm{H}, \mathrm{Ar}-\mathrm{H}), 10.21(\mathrm{~s}$, $1 \mathrm{H}, \mathrm{NH}) ;{ }^{13} \mathrm{C} \mathrm{NMR}\left(\mathrm{DMSO}-\mathrm{d}_{6}\right): \delta 24.20,118.37,121.32,128.57,130.98,134.65,142.12,167.65,171.12$; HRMS (Q-TOF) $\mathrm{m} / \mathrm{z}:[\mathrm{M}+\mathrm{H}]^{+}$Calcd for $\mathrm{C}_{9} \mathrm{H}_{10} \mathrm{NO}_{3}$ 180.0657, Found 180.0659 .

N-(4-hydroxy-2,3-dimethylphenyl)acetamide (Table 2, entry 16). m.p. $178{ }^{\circ} \mathrm{C}^{[35]}$; IR (KBr) 3312, 3182, 1664, $1505 \mathrm{~cm}^{-1} ;{ }^{1} \mathrm{H} \mathrm{NMR}\left(\mathrm{DMSO}-\mathrm{d}_{6}\right): \delta 2.06\left(\mathrm{~s}, 6 \mathrm{H}, \mathrm{CH}_{3}\right), 2.12\left(\mathrm{~s}, 3 \mathrm{H}, \mathrm{CH}_{3}\right), 6.75(\mathrm{~d}, \mathrm{~J}=8.0 \mathrm{~Hz}, 1 \mathrm{H}$, $A r-H), 7.43(d, J=8.0 \mathrm{~Hz}, 1 \mathrm{H}, \mathrm{Ar}-\mathrm{H}), 9.11(\mathrm{~s}, 1 \mathrm{H}, \mathrm{NH}), 9.80(\mathrm{~s}, 1 \mathrm{H}, \mathrm{Ar}-\mathrm{OH}),{ }^{13} \mathrm{C}$ NMR $\left(\mathrm{DMSO}-\mathrm{d}_{6}\right): \delta 21.51$, 22.31, 23.87, 118.33, 119.89, 121.54, 128.90, 132.78, 152.56, 168.22; HRMS (Q-TOF) $\mathrm{m} / z:[\mathrm{M}+\mathrm{H}]^{+}$Calcd for $\mathrm{C}_{10} \mathrm{H}_{14} \mathrm{NO}_{2}$ 180.1020, Found 180.1022.

N-(3-(1-hydroxyethyl)phenyl)acetamide (Table 2, entry 19). m.p. $260^{\circ} \mathrm{C}$; $I R(\mathrm{KBr}): 2932,1959,1732$, 1646, $1565 \mathrm{~cm}^{-1} ;{ }^{l} \mathrm{H} N M R\left(D M S O-\mathrm{d}_{6}\right): \delta 1.27\left(d, 3 \mathrm{H}, \mathrm{J}=6.39, \mathrm{CH}_{3}\right), 2.01\left(\mathrm{~s}, 3 \mathrm{H}, \mathrm{CH}_{3}\right), 4.65(\mathrm{~m}, \mathrm{lH}, \mathrm{CH})$, $5.15(d, 1 H, J=3.93, O H-e x c h),. 6.96(d, 1 H, J=7.77, A r-H), 7.18(t, 1 H, A r-H), 7.47(t, 1 H, A r-H)$, $8.10(s, 1 H, A r-H), 9.95(s, 1 H, N H) ;{ }^{13} C N M R\left(D M S O-d_{6}\right): \delta 21.40,21.83,70.07,120.49,121.92,125.31$, 130.22, 135.09, 142.58, 169.46; HRMS (Q-TOF) m/z: $\left[\mathrm{M}+\mathrm{H}^{+}\right.$Calcd for $\mathrm{C}_{10} \mathrm{H}_{14} \mathrm{NO}_{2}$ 180.1020, Found 180.1023. 
$N$-(2-(hydroxymethyl)phenyl)acetamide (Table 2, entry 20). m.p. $110{ }^{\circ} \mathrm{C}^{[37]}$; IR (KBr): 3429, 2935, 1598, $1463 \mathrm{~cm}^{-1},{ }_{1}^{1} \mathrm{H}$ NMR (DMSO-d $\left.\mathrm{d}_{6}\right) \delta 9.1(1 \mathrm{H}, \mathrm{s},-\mathrm{NH}), 7.35(\mathrm{~m}, 3 \mathrm{H}, \mathrm{Ar}-\mathrm{H}), 7.12(\mathrm{~m}, 1 \mathrm{H}, \mathrm{Ar}-\mathrm{H}), 4.65(\mathrm{~d}, \mathrm{~J}=$ $8.0 \mathrm{~Hz}, 2 \mathrm{H}$ ), $3.64(\mathrm{t}, 1 \mathrm{H},-\mathrm{OH}), 2.05\left(\mathrm{~s}, 3 \mathrm{H},-\mathrm{COCH}_{3}\right) .{ }^{13} \mathrm{C} \mathrm{NMR}\left(\mathrm{DMSO}-\mathrm{d}_{6}\right) \delta 224.2,59.6,114.8,125.3,127.8$, 130.3, 135.5, 146.1, 169.1; HRMS (Q-TOF) m/z: [M + H] Calcd for $\mathrm{C}_{9} \mathrm{H}_{12} \mathrm{NO}_{2}$ 166.0864, Found 166.0866.

3-acetamidobenzoic acid (Table 2, entry 21). m.p. $250{ }^{\circ} \mathrm{C}^{[30]}$; IR (KBr): 3300, 1690, 1539, $1445 \mathrm{~cm}^{-1}$; ${ }^{1} \mathrm{H} N M R\left(500 \mathrm{MHz}, \mathrm{DMSO}-d_{6}\right) \delta 2.04\left(\mathrm{~s}, 3 \mathrm{H}, \mathrm{CH}_{3}\right), 7.78-7.91(\mathrm{~m}, 3 \mathrm{H}, \mathrm{Ar}-\mathrm{H}), 8.29(\mathrm{~s}, 1 \mathrm{H}, \mathrm{Ar}-\mathrm{H}), 10.26(\mathrm{~s}, 1 \mathrm{H}$, $\mathrm{NH}), 12.9(\mathrm{~s}, 1 \mathrm{H}, \mathrm{br} . \mathrm{COOH}) ;{ }^{13} \mathrm{C} \mathrm{NMR}\left(\mathrm{DMSO}-\mathrm{d}_{6}\right): \delta 24.25,119.44,122.88,128.32,131.90,135.78,143.72$, 168.45, 170.42; HRMS (Q-TOF) m/z: $\left[\mathrm{M}+\mathrm{H}^{+}\right.$Calcd for $\mathrm{C}_{9} \mathrm{H}_{10} \mathrm{NO}_{3}$ 180.0657, Found 180.0659.

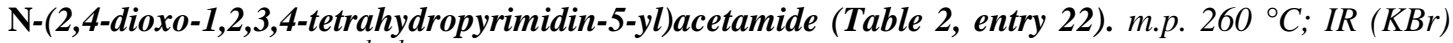
$3450,1626,1595,1498,1330 \mathrm{~cm}^{-1} ;{ }^{1} \mathrm{H} N M R\left(D M S O-d_{6}\right): \delta 2.01\left(\mathrm{~s}, 3 \mathrm{H}, \mathrm{CH}_{3}\right), 8.02(\mathrm{~d}, \mathrm{~J}=5.43 \mathrm{~Hz}, 1 \mathrm{H}$, vinylic $H), 9.10(s, 1 H, N H), 10.58(s, 1 H, N H), 11.40(s, 1 H, N H) ;{ }^{13} C N M R\left(D M S O-d_{6}\right): \delta 23.71,113.87,129.89$, 150.20, 161.23, 169.37; HRMS (Q-TOF) $\mathrm{m} / \mathrm{z}:[\mathrm{M}+\mathrm{H}]^{+}$Calcd for $\mathrm{C}_{6} \mathrm{H}_{8} \mathrm{~N}_{3} \mathrm{O}_{3}$ 170.0561, Found 170.0564 .

$N$-(6-methyl-2,4-dioxo-1,2,3,4-tetrahydropyrimidin-5-yl)acetamide (Table 2, entry 23). m.p. 195 ${ }^{\circ} \mathrm{C}^{[38]}$; IR (KBr): $3435,1618,1590,1470,1335 \mathrm{~cm}^{-1} ;{ }^{1} \mathrm{H}$ NMR (DMSO-d 6 ) $\delta 1.88\left(\mathrm{~s}, 3 \mathrm{H}, \mathrm{CH}_{3}\right), 1.92(\mathrm{~s}, 3 \mathrm{H}$, $\left.\mathrm{CH}_{3}\right), 8.8(\mathrm{~s}, 1 \mathrm{H}, \mathrm{NH}), 10.9(\mathrm{~s}, 1 \mathrm{H}, \mathrm{NH}), 11.1(\mathrm{~s}, 1 \mathrm{H}, \mathrm{NH}) \cdot{ }^{13} \mathrm{C}$ NMR (DMSO-d $\left.\mathrm{d}_{6}\right) \delta 169.2,161.8,150.4,149.1$, 108.5, 22.5, 15.4; HRMS (Q-TOF) m/z: [M + H] ${ }^{+}$Calcd for $\mathrm{C}_{7} \mathrm{H}_{10} \mathrm{~N}_{3} \mathrm{O}_{3}$ 184.0717, Found 184.0719.

$N$-phenylacetamide (Table 2, entry 24). m.p. $112{ }^{\circ} \mathrm{C}^{[30]}$; IR (KBr) 3298, 1667, 1598, $1562 \mathrm{~cm}^{-1} ;{ }^{1} \mathrm{H}$ NMR (DMSO- $\left.d_{6}\right): \delta 2.08\left(\mathrm{~s}, 3 \mathrm{H}, \mathrm{CH}_{3}\right), 7.07(\mathrm{~m}, 1 \mathrm{H}, \mathrm{Ar}-\mathrm{H}), 7.35(\mathrm{t}, 2 \mathrm{H}, \mathrm{Ar}-\mathrm{H}), 7.72(\mathrm{~d}, \mathrm{~J}=7.5 \mathrm{~Hz}, 2 \mathrm{H}, \mathrm{Ar}-\mathrm{H})$, $9.88(\mathrm{~s}, 1 \mathrm{H}, \mathrm{NH}) ;{ }^{13} \mathrm{C}$ NMR (DMSO- $\left.d_{6}\right): \delta 24.78,119.63$ (x2), 122.81, 128.95, 129.20, 139.12 168.90; HRMS (Q-TOF) $\mathrm{m} / \mathrm{z}:[\mathrm{M}+\mathrm{H}]^{+}$Calcd for $\mathrm{C}_{8} \mathrm{H}_{10} \mathrm{NO} 136.0759$, Found 136.0761 .

Methyl 3-acetamidobenzoate (Table 2, entry 35). m.p. $134{ }^{\circ} \mathrm{C}^{[19]}$; IR (KBr): 3290, 1725, 1680, 1530, $1430 \mathrm{~cm}^{-1} ;{ }^{1} \mathrm{H}$ NMR (DMSO-d 6 ) $\delta 2.04\left(\mathrm{~s}, 3 \mathrm{H}, \mathrm{CH}_{3}\right), 3.92\left(\mathrm{~s}, 3 \mathrm{H}, \mathrm{CH}_{3}\right) 7.76(\mathrm{~d}, \mathrm{~J}=8.0 \mathrm{~Hz}, 1 \mathrm{H}, \mathrm{Ar}-\mathrm{H}), 7.81-$ $7.91(\mathrm{~m}, 2 \mathrm{H}, \mathrm{Ar}-\mathrm{H}), 8.18(\mathrm{~s}, 1 \mathrm{H}, \mathrm{Ar}-\mathrm{H}), 10.18(\mathrm{~s}, 1 \mathrm{H}, \mathrm{NH}) ;{ }^{13} \mathrm{C}$ NMR (DMSO- $\left.d_{6}\right): \delta 24.79,52.96,119.56$, 123.90, 128.52, 132.78, 136.61, 141.98, 166.75, 168.56; HRMS (Q-TOF) m/z: $[\mathrm{M}+\mathrm{H}]^{+}$Calcd for $\mathrm{C}_{10} \mathrm{H}_{12} \mathrm{NO}_{3}$ 194.0813, Found 194.0815.

\section{CONCLUSION}

A facile one-pot eco-friendly expeditious protocol for the reductive acetylation of aromatic nitro compounds was developed. This method was successfully extended for the nitroso phenols and heteroaromatic nitro compounds. This methodology can be deployed as a substitute to the conventional two step reduction and acetylation process, which sometimes suffer from the problems of compromised yield resulting from the instability of the intermediate amine. This also paves way for the preparation of a suitable derivative for aromatic nitro compounds, which is otherwise difficult and cumbersome to achieve. However, this protocol is limited to the aromatic moiety having amino functionality which probably deactivates the catalyst. A thorough study on various substrates leads to a clear picture on the course of the reaction.

\section{Acknowledgements}

We are thankful to Prof. Nandita Basu (Ghorai), Director and Prof. Santanu Tripathi, Head of the Department of Clinical \& Experimental Pharmacology, School of Tropical Medicine, Kolkata for their interest in the work.

\section{REFERENCES}

[1] G. W. Kabalka, and R. S. Varma, Comprehensive Organic Synthesis: Selectivity, Strategy \& Efficiency in Modern Organic Chemistry (Trost B M, Fleming 1st ed.; Pergamon Press, 1991) 367.

[2] P. G. M. Wuts, and T. W. Greene, Greene's Protective Groups in Organic Synthesis (4th ed.; John Wiley \& Sons. Inc., 2007 ) 775.

[3] M. Kohn, and O. Krasso, A new application of reductive acetylation, J. Org. Chem. 13(3), 1948, 329.

[4] M. Freifelder, Isomeric Hydroxyacetanilides by Reductive Acylation of Nitrophenols, J. Org. Chem. 27 (3), 1962 , 1092.

[5] Y. L. Gol'dfarb, B. P. Fabrichnyi, and I. F. Shalavina, Reductive acetylation of nitro ketones of the thiophene series, Chem. Heterocycl. Compd. 18 (10), 1982, 1018.

[6] L. H. Klemm, and W. Hsin, Reductive acetylation of nitro compounds. III. Chemical transformations in three thiophene systems, J. Heterocyclic chem. 12 (6), 1975, 1183.

[7] Y. L. Gol'dfarb, V. N. bulgakova, and B. P. fabrichnyi, Reductive acetylation of nitrocarboxylic acids of the thiophene and furan series or their esters, Chem. Heterocycl. Compd. 19 (12), 1983, 1283.

[8] L. Fu, and G. W. gribble, Reductive acylation of 2- and 3-nitropyrroles - efficient syntheses of pyrrolylamides and pyrrolylimides, Tetrahedron lett., 48 (52), 2007, 9155.

[9] B. H. Kim, R. Han, F. Piao, Y. M. Jun, W. Baik, and B. M. Lee, Indium-mediated one-pot reductive conversion of nitroarenes to $n$ arylacetamides, Tetrahedron lett. 44 (1), 2003, 77. 
[10] Y. Jia, Q. Li, X. Wang, H. Wang, and X. Liu, Samarium-promoted one-pot reductive acylation of nitrobenzene to acetanilide, J. Shanghai univ. (english ed.), 10 (3), 2006, 277.

[11] X. Wang, H. Guo, G. Xie, and Y. Zhang, One-pot syntheses of amides from n-acylation of nitroarenes with esters mediated by samarium diiodide, Synth. Commun. 34 (16), 2004, 3001

[12] D. C. Owsley, and J. J. Bloomfield, The Reduction of Nitroarenes with Iron/Acetic Acid, Synthesis, 1977, 118.

[13] K. Y. Lee, J. M. Kim, and J. N. Kim, One-Pot Conversion of Nitroarenes into N-Arylamides, Bull. Korean Chem. Soc. 23 (10), 2002,1359

[14] T. Ho, Direct synthesis of anilides from nitroarenes, J. Org. Chem. 42 (23), 1977, 3755.

[15] R. N. Baruah, A novel one pot reductive acetylation of nitroarenes, Indian J. Chem. 39B, 2000, 300.

[16] Y. Watanabe, Y. Tsuji, T. Kondo, and R. Takeuchi, Platinum complex catalyzed reductive N-acylation of nitro compounds, J. Org. Chem. 49 (23), 1984, 4451.

[17] E. M. Nahmed, and G. Jenner, Synthesis of anilides by reductive N-acylation of nitroarenes mediated by methyl formate, Tetrahedron Lett. 32 (37), 1991, 4917.

[18] A. E. Wahba, J. Peng, and M. T. Hamann, Reductive amidation of nitroarenes: a practical approach for the amidation of natural products, Tetrahedron Lett. 50 (27), 2009, 3901.

[19] R. J. Rahaim, Jr., and R. E. Maleczka, Palladium-Catalyzed Silane/Siloxane Reductions in the One-Pot Conversion of Nitro Compounds into Their Amines, Hydroxylamines, Amides, Sulfonamides, and Carbamates, Synthesis, 19, $2006,3316$.

[20] D. R. Noguera, and D. L. Freedman, Reduction and Acetylation of 2,4-Dinitrotoluene by a Pseudomonas aeruginosa Strain, Appl. Environ. Microbiol. 62 (7), 1996, 2257.

[21] M. K. Lakshmi, R. S. Reddy, K. Srinivas, R. Chakravarti, B. Sreedhar, F. Figueras, and C. V. Reddy, Platinum nanoparticles supported on zirconia mediated synthesis of $\mathrm{N}$-acyl and $\mathrm{N}$-(tert-butoxycarbonyl)amines from nitroarenes and azides, J. Mol. Catal. A: Chemical 355, 2012, 96.

[22] E. H. Jensen, A Study on Sodium Borohydride with Special reference to its Analytical Application in Organic Chemistry (Nyt Fordisk Forlag, Arnold Busch, Copenhagen,1954).

[23] H. House, Modern Synthetic Reactions (2nd ed.; Benjamin Cummings Publishing Co., 1978) 52.

[24] E. A. Braude, R. P. Linstead, and K. R. H. Wooldridge, Hydrogen transfer. Part VII. Metal-catalysed transfer-hydrogenation of nitro-compounds, J. Chem. Soc. 1954, 3586.

[25] J. March, and M. B. Smith, March's Advanced Organic Chemistry (6th ed.; John Wiley \& Sons. Inc., 2007) 1818.

[26] E. Kremers, N. Wakeman, and R. M. Hixon, Thymoquinone, Org. Synth. Coll. Vol. 1, 1941,511.

[27] F. Alonso, I. P. Beletskaya, and M. Yus, Metal-Mediated Reductive Hydrodehalogenation of Organic Halides, Chem. Rev. 102, 2002, 4009.

[28] M. Petrini, R. Ballini, and G. Rosini, Reduction of Aliphatic and Aromatic Nitro Compounds with Sodium Borohydride in Tetrahydrofuran Using 10\% Palladium-on-Carbon as Catalyst, Synthesis, 8, 1987, 713.

[29] P. Albers, J. Pietsch, and S. F. Parker, Poisoning and deactivation of palladium catalysts, J. Mol. Catal. A: Chemical, 173, 2001, 275.

[30] B. S. Furniss, A. J. Hannaford, P. W. G. Smith, and A. R. Tatchell, Vogel's Textbook of Practical Organic Chemistry (5th ed.; Pearson Education, India, 2004) 1372.

[31] Y. Omote, T. Miyake, S. Ohmori, and N. Sugiyama, The Chemiluminescence of Luminol and Acetyl-luminol, Bull. Chem Soc. Jpn. 40, 1967, 899

[32] L. R. Cerecedo, and C. P. Sherwin, Comparative metabolism of certain aromatic acids: VII. Fate of $p$-chloro, $p$-bromo, and $p$-amino acids in the dog, the rabbit, and man, J. Biol. Chem. 62, 1924, 217.

[33] S. Chakraborty, G. Chattopadhyay, and C. Saha, A Novel CAN-SiO2-Mediated One-Pot Oxidation of 1-Keto-1,2,3,4tetrahydrocarbazoles to Carbazoloquinones: Efficient Syntheses of Murrayaquinone A and Koeniginequinone A, J. Het. Chem. 48 (2), 2011, 331 .

[34] P. Leggate, and G. E. Dunn, Application of the extended hammett relationship to the ionization constants of substituted anthranilic acids, Can. J. Chem. 43 (5), 1965, 1158.

[35] D. Leuchs, Neue Synthese von $p$-Hydroxy-azobenzolverbindungen, Chem. Berichte. 98, 1965,1335.

[36] A. P. Avdeenko, S. A. Konovalova, O. N. Ludchenko, O. P. Ledeneva, and A. V. Vakulenko, Hydrohalogenation of $N$ acetyl(aroyl)-1,4-benzoquinone monoamines, Russ. J. Org. Chem. 47 (2), 2011, 214

[37] L. C. Raiford, and E. P. Clark, Behavior of mixed O-acyl-N-acyl derivatives in which the reacting groups are not on adjacent carbon atoms, J. Am. Chem. Soc. 48 (2), 1926, 483.

[38] R. Behrend, Versuche zur Synthese von Körpern der Harnsäurereihe, Justus Liebigs Ann. Chem. 231 (2), 1885, 248.

[39] J. P. Brown, G. V. McGarraugh, T. M. Parkinson, R. E. Wingard, Jr., A. B. Onderdonk, A polymeric drug for treatment of inflammatory bowel disease, J. Med. Chem. 26 (9), 1983, 1300.

[40] R. J. Rahaim, Jr., and R. E. Maleczka, Palladium-Catalyzed Silane/Siloxane Reductions in the One-Pot Conversion of Nitro Compounds into Their Amines, Hydroxylamines, Amides, Sulfonamides, and Carbamates, Synthesis, 19, $2006,3316$. 


\section{SPECTRA OF UNKNOWN COMPOUNDS}

PD-2003-1H (ND)

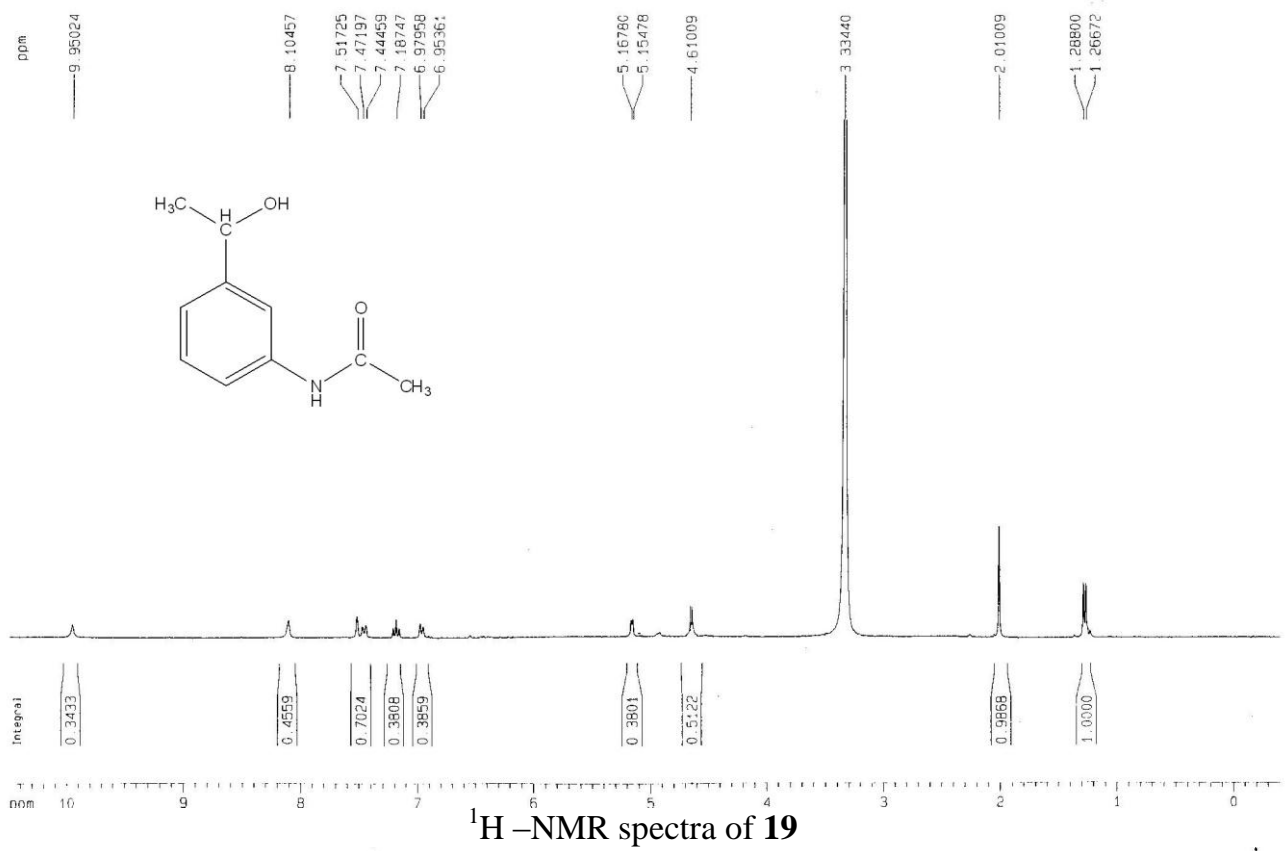

$13 \mathrm{C}$ spectrum of CS/STM/S-71 in DMSO-d6

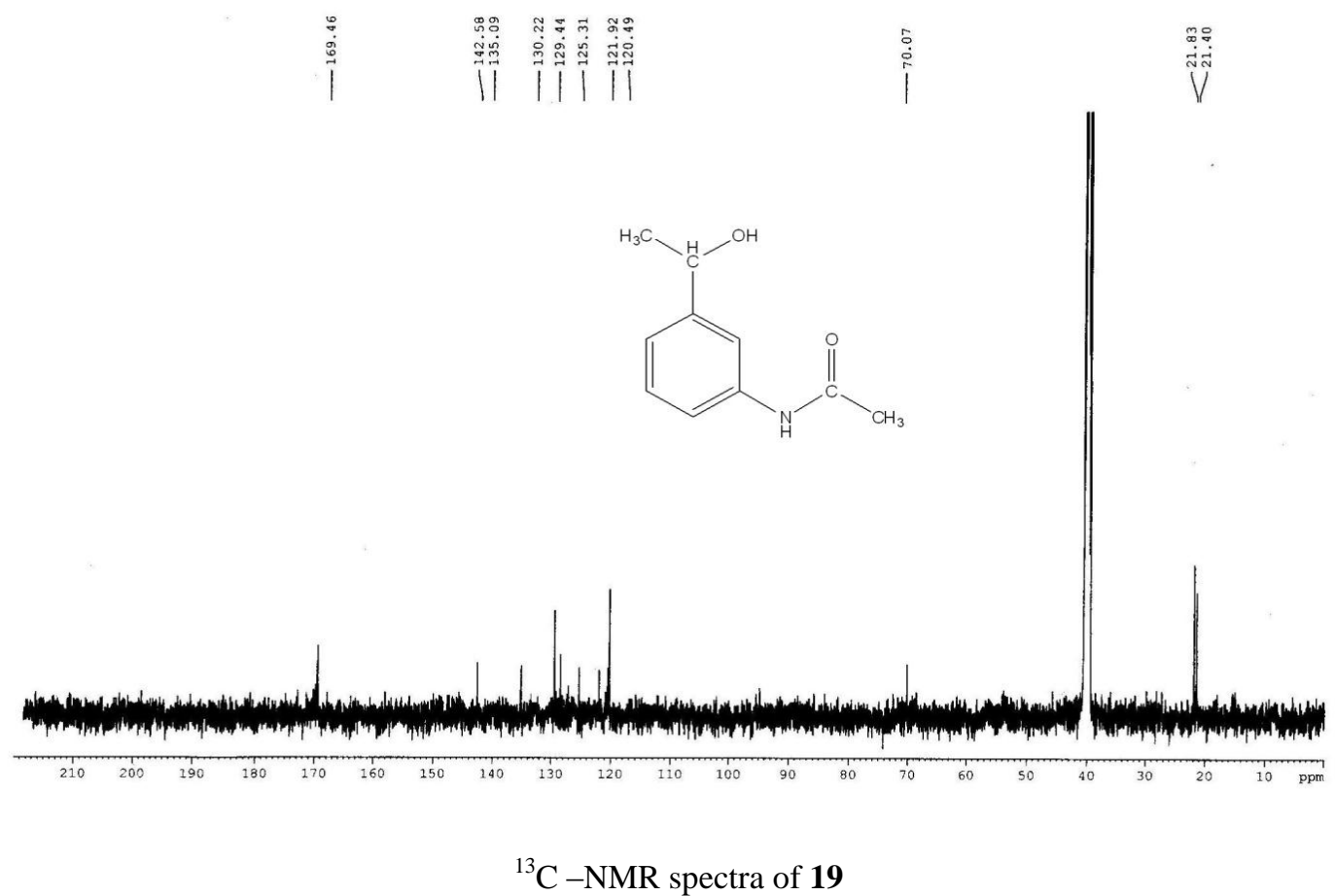


AD2002-1H (SKD)

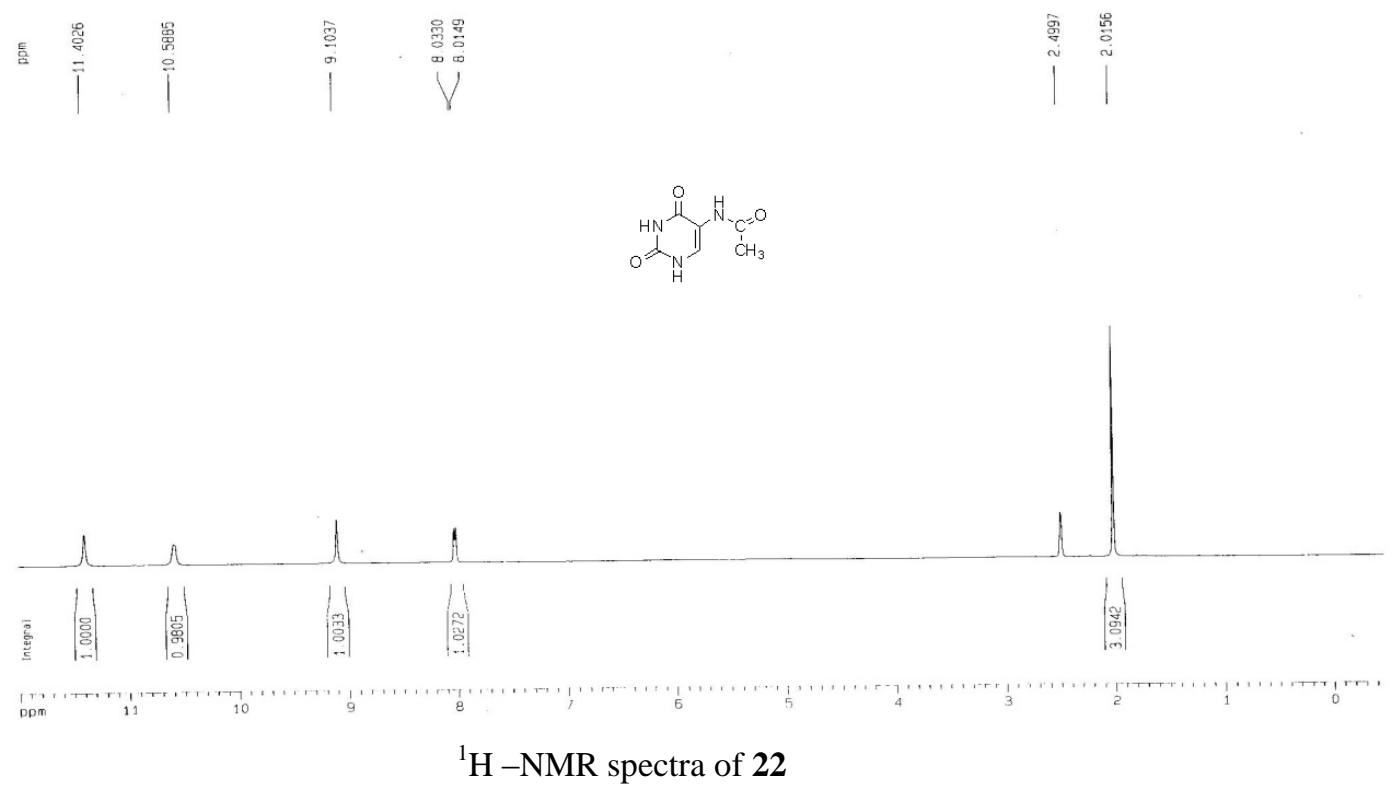

RO2002-13C

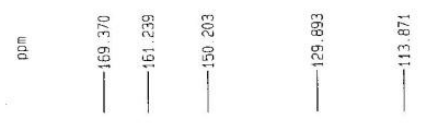

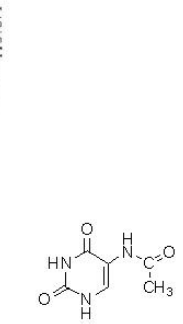

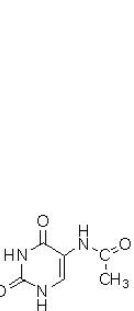

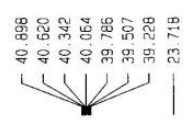

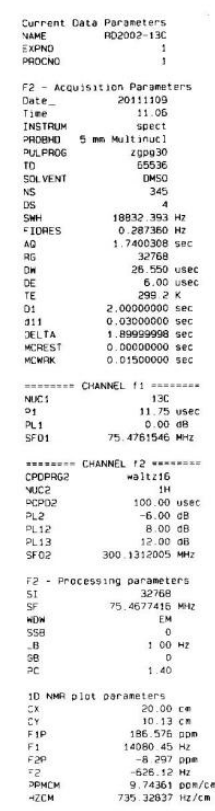

${ }^{13} \mathrm{C}-\mathrm{NMR}$ spectra of 22 